\title{
Some Aspects of Harmonisation of Ukraine's Competition Legislation to EU Standards
}

\author{
Olga O. Bakalinska ${ }^{1, *}$, Valeriy I. Polyukhovych ${ }^{1}$, Volodymyr I. Korol ${ }^{2}$ and Oksana V. Kiriiak ${ }^{3}$ \\ ${ }^{1}$ Department of Legal Support of Market Economy, Academician F.H. Burchak and Scientific Research \\ Institute of Private Law and Entrepreneurship of the National Academy of Legal Sciences of Ukraine, Kyiv, \\ Ukraine \\ ${ }^{2}$ Department of the International Private and Comparative Law, Academician F.H. Burchak and Scientific \\ Research Institute of Private Law and Entrepreneurship of the National Academy of Legal Sciences of \\ Ukraine, Kyiv, Ukraine \\ ${ }^{3}$ Faculty of Law, Yuriy Fedkovych Chernivtsi National University, Chernivtsi, Ukraine
}

\begin{abstract}
In modern conditions, obtaining information about market dynamics, trends in demand, and alternative offers from competitors is vital to support the effective operation of enterprises. It is also common business practice to discuss legislative initiatives, non-confidential technical information, quality and safety standards, and various aspects of the industry. However, the direct or indirect exchange of information may be accompanied by various wrongful intentions of economic entities (for example, elimination of competitors, creation of entry barriers, agreement on price levels, certain discounts, sales volumes, and the market's geographical distribution, etc.). In Ukraine, there are currently no analogues of a full-fledged guide to information exchange between competitors, which determined the relevance of this study. The purpose of the study is to establish regulatory, economic principles for assessing the exchange of information between enterprises operating in the relevant market, in the context of compliance with legislation on protection of economic competition; analysis of the progressive international practice of cessation of violations in the form of information exchange, which leads to distortion of economic competition. In Ukraine, it is necessary to adopt the Guidelines for the Exchange of Information between Competitors (from now on referred to as "the Guidelines"), raising awareness of the business community (including associations and chambers of commerce), lawyers, and society in general regarding the main aspects of the competition compliance with competition law in order to promote fair business activities, protect the competitive environment and, as a consequence, improve consumer welfare.
\end{abstract}

Keywords: Antimonopoly Committee of Ukraine, anti-competitive consequences, competition legislation, oligopolistic market, conspiracy.

\section{INTRODUCTION}

Obtaining information and, in particular, the exchange of certain data may carry significant risks of distortion of the competitive environment, which means that under certain conditions such actions may be considered by the competition authority as an anticompetitive practice. In this regard, the question remains as to the line between lawful action and violation of legislation on economic competition protection. In practice, the assessment of the admissibility of information exchange is usually accompanied by many enforcement issues, including collecting the relevant evidence of informal arrangements, especially the proving of a causal link between the information exchanged and changes in the relevant market. This is an issue that competition authorities often encounter, especially in cases where it is necessary to prove the restriction of competition in terms of consequences.

*Address correspondence to this author at the Academician F.H. Burchak and Scientific Research Institute of Private Law and Entrepreneurship of the National Academy of Legal Sciences of Ukraine, Kyiv, Ukraine;

Tel: (044) 25654 85; E-mail: oo_bakalinska@uohk.com.cn
Notably, from the standpoint of protecting the effective competitive environment, the most dangerous (anti-competitive) manifestations are the development of practical co-operation between the enterprises as a result of data exchanges. Antitrust investigations increasingly often occur in associations, consulting, marketing agencies, and sociological organisations, through which businesses can obtain individualised information about the market, market trends, etc. For example, back in 2009, the European Commission proved a cartel conspiracy in the market of thermal stabilisers with the participation of a Swiss consulting firm that ensured the functioning of the cartel. According to the investigation, the consulting firm acted as a driver for the exchange of market-sensitive information - collecting information and further disseminating it to cartel members. This raises the issue of what information and in what cases may cause risks of infringement of competition law.

In the European Union, there is a European Commission Directive on the application of Article 101 of the Treaty on the Functioning of the EU on horizontal co-operation agreements (Consolidated version of the 
treaty... 2012), the vast majority of EU member states have an internal explanatory document on this matter and relevant practice. European Union competition law makes provision for an exception: information exchange agreements that violate Article 101 of the Treaty on the Functioning of the European Union (TFEU) may not be covered by this rule if they create cost-effectiveness for consumers and there are no alternatives other than information exchange to create such efficiency and if the parties to the information exchange agreement do not have significant market power. An analysis of current European legal practice indicates that agreements on the exchange of information between competitors considered by the European Commission are usually covered by Article 101 of the TFEU. However, information exchange agreements can be considered as a separate violation of competition law, or as part of another violation - the relevant agreement (for example, a cartel) between competitors. In cases where the exchange of information is part of another agreement between competitors, it must be evaluated together with the latter. This study focuses on the analysis of information exchange between competitors, which can be qualified as an individual violation of competition law.

In December 2009, the Competition Bureau of Canada published a number of Guidelines to Competitors' Co-operation (Government of Canada 2009). The documents address the exchange of information between competitors, both in the form of direct and indirect exchanges and through trade associations. The Guidelines state that, for the most part, such exchanges do not violate the law, as competitors usually avoid sharing information in order to maintain a competitive advantage. In some cases, an agreement that makes provision for the unilateral disclosure or exchange of information between competitors may distort competition by reducing uncertainty about competitors' strategies and reducing the commercial independence of each exchange participant. Thus, in assessing information exchange agreements between competitors, the Competition Bureau of Canada analyses the following factors: the nature of the information exchanged, the timing of information exchange, market power, the order in which information is collected and disseminated, (compensation for anti-competitive effects of information exchange). For example, in Mexico, constitutional changes took place in 2013, and the new Federal Law on Economic Competition (Comisión Federal... 2015) came into force in 2014. Since the discussion of the new Law on Economic Competition, the issue of information exchange has caused great uncertainty for companies. The Fair Trade Commission of Japan published a Guide to Trade Associations, which was harmonised with antitrust law in October 1995 (Information Exchanges... 2010). Although the Guide directly addresses the potential impact on competition through trade associations, a detailed assessment of trade association information exchange by the Fair Trade Commission of Japan can be applied even outside the context of a trade association. The Fair Trade Commission of Japan assumes that the tacit conspiracy will certainly facilitate the exchange of information, in particular related to important competitive factors concerning the current or future business activities of the firms involved.

The issue of information exchange is partially regulated only within the framework of the assessment of anti-competitive risks in the establishment of business associations; namely, the parameters are set, in compliance with which the permission of the Antimonopoly Committee of Ukraine for concerted actions is not required. In particular, the Committee's standard requirements for establishing an association include an exclusive list of data that the association may collect about its members (such as data on technical and scientific information, data on efficient technologies and cost-cutting tools, environmentally friendly technologies; industry problems and solutions, foreign experience, information for co-operation with public authorities and other organisations).

Given the above issues, the main objectives of the study are as follows:

- analysis of factors that determine whether the exchange of information is inconsistent with competition legislation;

- $\quad$ analysis of European practice of termination of violations in the form of exchange of information between competitors, which has led/may lead to distortion of economic competition;

- development of proposals on the qualification of violations of the legislation on protection of economic competition in the form of anticompetitive information exchanges between the enterprises operating in the corresponding market, taking into account results of consideration of similar cases in the member states of the European Union. 
Studies of many scientists address the analysis of the specific features of information exchange among competitors in the context of compliance with competition legislation. Scientists investigate the permissible and illegal forms of information exchange in the context of protection of economic competition, criteria for assessing the content of information exchanged, the risks of enterprises under investigation by the competition authority, the specifics of cases of termination of competition law in the form of anticompetitive information exchanges.

\section{ANALYSIS OF EUROPEAN PRACTICE OF DETECTING AND TERMINATING VIOLATIONS OF COMPETITION LEGISLATION}

Review of cases of detection and termination of violations of competition legislation in the form of illegal information exchanges between enterprises operating in the relevant market allows to develop scientifically sound proposals on the criteria of admissibility of data exchange in terms of preventing elimination or distortion of economic competition; factors that should provide a deterrent effect for market participants from similar wrongdoing in the future; the necessary powers of the Antimonopoly Committee of Ukraine in the context of detection, investigation, termination of this category of offences.

EU competition law lacks clear rules governing the exchange of information between competitors. Article 101(1) of the Treaty on the Functioning of the European Union (TFEU) (2012), which prohibits agreements between undertakings incompatible with the internal market, decisions by associations and concerted practices which may affect trade between the Member States, and which are intended to or lead to the prevention, restriction, or distortion of competition in the internal market, there is no clear prohibition on concluding an information exchange agreement. Thus, the current regulation of information exchange agreements is based on the case-law of the European Commission and the European Courts on the application and interpretation of Article 101 of the TFEU. Article 101 of the TFEU can be applied to treaties, including information exchange agreements, which meet four conditions: agreements between undertakings, restrictions of competition, significant effects on competition, and influence on trade.

In several documents, the European Commission has made recommendations on the legal assessment of such agreements. The first document of this kind is the Notice of the European Commission on
Cooperation Agreements (1968) (Information Exchanges... 2010; Švirinas 2012). This Notice states for the first time that the exchange of information between competitors may in some cases violate Article 101 of the TFEU, but in each particular case, it is necessary to assess information about the market (its structure) and analyse other important factors.

The Notice identified the following factors that may influence such an assessment, namely (Information Exchanges... 2010):

- $\quad$ only the exchange of information that may affect competition is relevant in accordance with competition rules;

- restrictions of competition are more likely in oligopolistic markets for homogeneous goods.

For example, if post-exchange information is used to restrict the ability of enterprises to operate freely in the market, and the exchange of information itself takes place to coordinate the actions of enterprises, it is likely that it will be considered as such that is restricting competition.

In the VII Report on Competition Policy of the European Commission (1978), a separate part was covered the information exchange agreements. The Report noted that the exchange of information does not constitute a restriction of competition as such; therefore, it is necessary to assess the impact of such an agreement on competition in the corresponding (relevant) market (Information Exchanges... 2010; Švirinas 2012). In its report, the European Commission identified three main criteria to be followed upon considering such situations:

Firstly, when assessing the consequences of such transactions, it is necessary to take into account, above all, the structure of the market. The structure of the market may affect the probability that these types of contacts will create incentives for coordinated behaviour between competitors (market participants). Increased transparency resulting from the exchange of information strengthens the interdependence between firms and reduces the intensity of competition in oligopolistic markets, as expanding market knowledge (i.e., transparency) allows participants to track competitors' strategies and respond quickly (and effectively) to each other's actions.

Secondly, the nature and extent of information exchange are important to assess the probability that 
this information may actually be used by the recipient to coordinate market strategies rather than to achieve more intense competition.

Thirdly, whether the exchange of information is private, because this form of co-operation between enterprises usually improves knowledge of market conditions, or can have a broad public impact on consumers, and therefore creates an opportunity to compare different proposals and increase competition (Information Exchanges... 2010).

Although the first political statement of the European Commission on the evaluation of information exchange dates back to 1968 , in practice it was made only in the early 1990s in the case of assessing the admissibility of information exchange in the market of agricultural tractors in the UK (Information Exchanges... 2010; Commission Decision... 1992). In this case, the European Commission conducted a comprehensive assessment of the potential restrictive effects of the autonomous information exchange system. The decision of the European Commission was considered on appeal and by the European Court. Both courts rejected the complaints and fully supported the approach of the European Commission (Information Exchanges... 2010). Following the case in the United Kingdom, the European Commission began to apply the principles stipulated in the various decisions in order to further clarify their scope. Notably, the decision in the case in the United Kingdom led to numerous appeals from businesses seeking individual exemption from liability for possible violations of Article 101(3) of the TFEU.

The Guidelines on the applicability of Article 101 of the Treaty on the Functioning of the European Union to horizontal co-operation agreements (Communication from the Commission... 2011) (hereinafter referred to as "the Treaty") have replaced the European Commission Notice on Cooperation Agreements of 1968. They lack a separate chapter on the exchange of information. In paragraph 10 of the Guidelines, the European Commission has clarified that they do not regulate the above agreements and that some types of horizontal agreements between competitors (for example, information exchange agreements) are considered separately. For example, it is stated that commercialisation schemes arising from joint sales raise two important issues, one of which is "a clear opportunity to exchange classified commercial information, in particular on marketing strategy and pricing" (Paragraph 146). Paragraph 150 of the
Guidelines also state that the more concentrated the market, the more useful information on prices or marketing strategies is to reduce uncertainty, the more incentives there are for market participants to share such information (Švirinas 2012).

After revising the 2001 Guidelines 10 years later, the European Commission analysed separately and in sufficient detail the information exchange agreements in paragraphs 55 to 110 of its Communication "Recommendations on the application of Article 101 of the Treaty on the Functioning of the European Union to horizontal co-operation agreements" (hereinafter referred to as the Communication) (Švirinas 2012; Communication from the Commission... 2011; Commission's Guidelines... 2001). The rules set out in this Communication on information exchange agreements constitute the most thorough study of the European Commission, which not only summarises the legal practices of the European Commission and the Court of Justice but also represents the quintessence of the European Commission's critical opinion. The relevant rules of the Communication will be analysed in more detail below when considering specific aspects of information exchange.

Specific Guidelines for the exchange of information between competitors should be considered in the broader context of the revision of the competition rules applicable to the various forms of competition between competitors (actual or potential). The drafts of the three documents were published by the European Commission for comment from stakeholders. Firstly, two exemptions from the project (exemptions) - for research and development (R\&D) agreements and special arrangements - have been published (and are intended to replace the existing block exemptions, which expired on 31 December 2010). In addition, the European Commission has published a carefully analysed and expanded version of the Guidelines for Horizontal Cooperation Agreements (2001). The European Commission has filled an important gap with a new section of competition legislation to assess the exchange of information. Prior to that, there were no clear rules for assessing the admissibility of the exchange of information between competitors - except for the maritime sector - and only the Court's case law and the European Commission's decision-making practice could be relied upon. One of the greatest advantages of the Guidelines is that, for the first time, well-organised and clear evaluation conditions are offered (European rules... 2010). The Guidelines do not apply to forms of information exchange that aim to 
establish or facilitate prohibited price-fixing and market sharing agreements. The assessment of such forms of information exchange within the framework of the competition legislation is not particularly difficult: in principle, they will always be considered (and fined) as illegal cartels.

The European Commission has focused on assessing the situation where the exchange of information exists as a fact, independently of any cartel, where the main economic process is essentially the exchange of information (for example, the exchange of sectoral statistics with or without an association). The document clearly states the position of the European Commission that the exchange of information often promotes competition, as companies gain a deeper understanding of the market, which can lead to significant efficiencies. However, some forms of information exchange increase market transparency to such an extent that companies become aware of the market strategies of their competitors, which may result in the coordination of their competitive behaviour. The European Commission considers that only in exceptional situations can it be demonstrated sufficiently effectively that this form of information exchange is acceptable (European rules... 2010).

\section{INFORMATION EXCHANGE: TYPES, IMPACT, LEGAL FRAMEWORK AND KEY THREATS TO THE COMPETITIVE ENVIRONMENT}

As already mentioned, the impact of information exchange on competition must be assessed on a caseby-case basis. The probable negative impact of information exchange on the most important parameters of competition, such as prices, production volumes, product quality, product range and innovation, etc., should be considered. Therefore, this study investigates the most important parameters and features of the relevant market, which must be analysed upon establishing the fact of anti-competitive impact of information exchange on economic competition.

In modern conditions of market relations, the ability to exchange information between competitors is of paramount importance for the effective implementation of economic activity in the market. Access to reliable information about the state of the market can allow companies to effectively plan and forecast their production and commercial activities, as well as invest in new production facilities or research and development, which, in turn, can improve quality and reduce prices for the offered goods and services and increase innovation (Sofia Competition Forum 2011; Information cartels... 2016; Sloan 2014).

Sharing information can also benefit consumers by lowering search costs, which directly leads to better welfare. Consumers will be capable of making an effective choice only if they are well informed about the prices, characteristics, features of use, and quality of various goods offered on the market. Obviously, one of the prerequisites for the development of effective competition in the market for consumers is to enable them to compare prices and commercial conditions offered by different suppliers of goods or services. The presence of such an opportunity indicates the provision of a certain level of market transparency, which, in turn, constitutes a necessary condition for the development of a competitive market process (Sofia Competition Forum 2011; Lourenço 2017; Behar-Touchais 2015; OECD 2014).

The exchange of market information, which increases market transparency, is necessary for effective competition, as long as it does not create the conditions for concerted or coordinated behaviour of market participants. In this context, it is possible to identify legitimate sources of information about competitors. The openness of information, both for businesses and consumers, helps to increase transparency, which is one of the factors necessary to ensure market stability. Therewith, the artificial elimination of uncertainty about the actions of competitors, which, inter alia, is an inherent feature of competition, can in itself preclude normal competition. This is especially true for highly concentrated markets, where increased transparency allows companies to better predict or anticipate the behaviour of their competitors and adapt to them (Sattler 2012; Boychuk, 2017; Skliar 2014). Thus, in the understanding of competition legislation, information exchange constitutes a form of horizontal co-operation between competitors, through which they offer each other directly or indirectly, unilaterally or bilaterally, historical, current or forecast data on important parameters of their business.

An analysis of the current practices of competing agencies indicates that business associations can play a leading role in the exchange of information between competitors. Despite the undeniably useful activities they carry out in terms of economic development, associations often function as centres for the accumulation and exchange of confidential commercial 
information between their members. Such co-operation between enterprises is subject to legal regulation under competition law, as it can lead to pro- or anticompetitive effects in at least three areas: the way in which individual enterprises are guided in making economic decisions; the way in which customers are guided in choosing the appropriate products; as well as ways of competitive pressure that are implemented by participants in the relevant market (Sofia Competition Forum 2011; OECD 2016).

The issues of access, exchange, and use of information are crucial for building an effective business strategy. However, such a seemingly ordinary process can create antitrust risks for the company. The competition authority may assess this process of exchanging and using the information as evidence of anti-competitive concerted actions. The exchange of information between competitors can take various forms (so-called coordination of prices for goods and services, division of markets, elimination of competitors from the market or restriction of market access to potential competitors, etc.); it can increase or restrict competition (Sofia Competition Forum 2011; OECD 2016).

First of all, when assessing the exchange of information as a potential violation of competition legislation, the following should be established: whether it is part of another form of prohibited horizontal co-operation between enterprises and can, in essence, be a mechanism that facilitates or controls the implementation of anti-competitive practices in the market as a cartel; whether it is an independent form of co-operation and distorts competition unassisted due to the anti-competitive effects it causes or may cause. When the exchange of information between competitors takes place in the context of another form of prohibited horizontal co-operation between undertakings (for example, a cartel as the most serious breach of competition law), it must be analysed in the context of the investigation of the breach. For example, the exchange of information can serve to enhance the internal stability of a cartel by giving the participating companies the necessary level of market transparency, i.e., by helping them to control the companies' compliance behaviour, and by taking appropriate measures and sanctions for non-compliance. The exchange of information can also be a mechanism to enhance the external stability of the cartel by giving participating companies the opportunity to monitor potential new entrants and to take concerted action to eliminate potential competitors. The advantage, in this case, is that the assessment of information exchange as a form of prohibited behaviour does not require additional economic analysis of its anti-competitive effects. In this case, the exchange of information is prohibited in itself in accordance with Article 101(1) of the TFEU. The main difficulties in establishing this form of prohibited exchange of information between competitors are related to the requirement to find more solid evidence regarding the cartel itself (Sofia Competition Forum 2011; Papp 2013). The exchange of information can constitute an independent form of horizontal co-operation between competitors, manifested in one of three forms of prohibited conduct of enterprises under Article 101(1) of the TFEU: agreements between enterprises, decisions of associations, concerted actions (Papp 2013; Horizontal Information Exchanges 2012; McDavid and De Stefano 2016).

The exchange of information between undertakings should be considered as a separate form of prohibited conduct only when it is intended to prevent or restrict or distort competition in the relevant market. Specific manifestations of prohibited anti-competitive behaviour of enterprises, in particular, are defined in Article 101(1) of the TFEU, namely: setting prices or other conditions of trade; division of markets or sources of supply; restriction or control of production, trade, technical development or investment, etc. Therefore, information that can be restricted in the competition is often related to the following parameters of competitors' economic behaviour: prices, volumes, suppliers and customers, introduction or closure of production facilities, application of technologies and standards, etc. (Sofia Competition Forum 2011; OECD 2016).

When establishing the compliance of information exchange between competitors to the rules of competition law, it is important to analyse the terms of the agreement between enterprises (Švirinas 2012). This condition is necessary to qualify an infringement in accordance with Article 101 of the TFEU or an article of the national law on economic competition. If competitors exchange information without concluding an agreement within the meaning of Article 101 of the TFEU or an article of national economic competition law (i.e., in the form of an agreement, concerted practise or decision of the association), the relevant articles cannot be applied. This is stated in the Communication: "the exchange of information may be decided only in accordance with Article 101 if it is approved or is part of a contract, agreed practice or 
decision of an association of undertakings" (paragraph 60) (Švirinas 2012).

For example, if a competitor's confidential information becomes available to businesses not directly but through the media or other third parties, this should not be construed as an agreement. Or, if a third party (marketing agency) individually collects, systematises and provides information to its customers, even if such information is received from competing companies, such information should also not be considered as an agreement to exchange information, despite the fact that competitors receive information about each other (Verkhovna Rada of Ukraine 2001). In the Communication, the European Commission states that one of the forms of concerted practice in the presence of an agreement may be the creation of a situation where only one company discloses strategic information to its competitor(s).

Therefore, if one competitor publicly discloses certain information that will not be exchanged and that becomes known to another competitor, the fact of the agreement may be established, except that the participant who received the information clearly did not wish to receive such information. For example, if an employee of one company emails information on the company's sales volume, and an employee of another company who receives this information by email does not respond in any way to the information received (for example, believing that this information is not important) and does not reply that he or she does not want to receive such information, then, according to the logic of the European Commission, it can be stated that an agreement on the exchange of information has been concluded. This conclusion cannot be considered valid, as, according to experts, in this situation, the act of coordination of actions is clearly lacking (Švirinas 2012; Bakalinska et al. 2017).

One of the rare cases where information was publicly declared, and no de facto agreement was reached was analysed in the Wood Pulp case (the cellulose case). Businesses have publicly announced price increases, information has been spread very quickly among traders and buyers through the local media, and no agreement has been announced between competitors. The European Commission took two factors into account when deciding on the existence of concerted action. Firstly, there was a direct and indirect exchange of information between enterprises, resulting in the creation of artificial transparency regarding price information in the market.
Secondly, the economic analysis indicated that the market was not purely oligopolistic, in which the existence of parallel prices would be possible. Most probably, the market was competitive: sellers were dealing with a variety of products, competitors were dealing with different cost structures, they were located in different countries and had to set different prices in the absence of conflicts. Therefore, the only explanation for the parallel setting of prices was, according to the European Commission, the concerted actions of enterprises (Lourenço 2017). The European Commission Communication states that concerted action cannot be ruled out, for example, in a situation where a unilateral and public announcement made by a company (for example in a newspaper) provokes public statements from competitors, not least because strategic Competitors' responses to each other in public statements can be a strategy for reaching a common understanding of the coordination plan (Švirinas 2012).

Based on the position of the European Commission, it is problematic when a company announces information on its website, for example, regarding the reduction of prices for its services, which will be valid for one month, and a competitor after reviewing this notice will announce a reduction in its prices for the same period. From the explanations of the European Commission provided in the Communication, one thing is clear - the European Commission will need very little information to analyse the agreements concerning the exchange of information for compliance with competition legislation in cases where the information of one competitor "reaches" another competitor, and the latter does not state that he or she did not want to receive information and did not want to receive it in the future (Švirinas 2012).

It is considered that the agreement can be identified only in cases where the association, as an intermediary for its members, collects confidential information from them and provides access to it to members, or distributes data between them. Therefore, if the third party through which the information was exchanged is a business combination, the agreement is likely to take the form of a business combination decision. Obviously, the form of the agreement - the agreed (cartel) practice or the decision of the association - will not be decisive in this case. The European Commission assumes that a situation where an association of private companies $X$ disseminates individualised information about potential future prices only to its members should be considered as an 
exchange of information to restrict competition and the European Commission will not even determine whether it is an association agreement or a decision. (Paragraph 105 of the Communication) (Notice concerning agreements... 1968; Federal Trade Commission... 2000).

In addition to the specified types of information exchange, there are also the following ones:

I. Direct and vertical exchanges. Direct exchanges between competitors are the most obvious ways to exchange data. Any agreement between competitors on this matter falls within the scope of Article 101 of the TFEU. The lack of acceptable data in the direct exchange of information is unlikely to conceal the anticompetitive nature of such agreements. Following the UK Agricultural Tractor case, the European Commission questioned the legality of the vertical exchange of information between producers and retailers, finding that such exchange was not objectionable if the information provided concerned only the retail sales of the producer concerned. In addition, such an exchange of information violates Article 101 of the TFEU if: 1) it allows the identification of competitors' sales; 2) such information prevents the retail activities of dealers or parallel importers.

II. Dissemination of market data by independent third parties. In many cases, information on the market structure is disseminated by independent consultants whose activities include market monitoring, collection, aggregation, and sale of industry data and market research for market participants. Although these studies may constitute a source of confidential information for market participants (in particular, market shares), the European Commission generally accepts the legitimacy of such activities due to the following reasons:

- firstly, in such cases, there is no real exchange of information between competitors, as the information is collected independently by the consulting company from the market and not directly from the participants. Therefore, one of the conditions for the application of the requirement of Article 101 of the TFEU (i.e., the existence of an agreement between competitors) is not met;
- $\quad$ secondly, the information used for this market research is usually publicly available; as noted above, if the market itself is transparent, the exchange of information does not create any risk of collusion;

- thirdly, the use of specialised consultants to gather marketing information saves money, which increases the efficiency of the company's business.

However, if the results of a market study prepared by an independent consultant are jointly shared by market participants (i.e., there is an agreement between competitors to provide a joint mandate to the consultant), the consultant may play a role similar to a trade association and the risks of violating the competition law would be rather high (Information Exchanges... 2010).

Thus, each entity must independently determine the market policy that it intends to follow. It is for this reason that businesses are not allowed to establish any direct or indirect contacts with other operators that may influence the behaviour of competitors or disclose their own current or future behaviour if the purpose or consequences of these contacts create conditions of competition that do not correspond to the usual conditions for the relevant market (Sofia Competition Forum 2011; Federal Trade Commission... 2000). The advantage of assessing the exchange of information as a separate violation of competition rules is that the collection of evidence is relatively simplified. The main difficulties are related to the in-depth economic evaluation of the evidence gathered, which should confirm or refute the anti-competitive effect (purpose or consequences) of a particular exchange of information between competitors (European rules... 2010).

\section{STRATEGIC TYPES OF INFORMATION IN TERMS OF ANTI-COMPETITIVE EFFECTS}

The qualification of violation of competition legislation in the form of illegal information exchange will depend on numerous parameters of information, such as its content, nature, level of detail, antiquity of information, how often and in what way information is exchanged, etc. Below, the study considers them in more detail.

\section{Strategic (Confidential) Commercial Information}

The exchange of non-public and especially confidential information is problematic from the 
standpoint of compliance with competition legislation. For the purposes of competitive analysis, information that is equally available to all relevant market participants and consumers, including entities that do not take part in the exchange of information, is considered public. Businesses, for example, are required to publish their annual financial statements, which include cost and revenue data. Moreover, in carrying out their business activities, companies usually disclose information to their customers and consumers about prices, quality, features, and use of goods and services. This information exists in the so-called "free access" and can be obtained without any obstacles. As a result, access to such information does not require the creation of a specific exchange system. This is the reason why competitors, as a rule, do not take part in the work of coordination mechanisms for the exchange of such information. Next, the study considers the most important types of information that are strategic in terms of the occurrence of anti-competitive effects, in particular the implementation of a probable conspiracy:

\section{Price}

In some circumstances, the exchange of price information can have pro-competitive effects: for example, the exchange of information on current prices for input materials (for example, workforce, raw materials) can reduce the cost of finding companies, which usually aims to benefit consumers through lower sales price. However, in the vast majority of cases, the exchange of price information has anti-competitive effects.

\section{Quantity}

The exchange of information on future or previous volumes has the same effect as the exchange of information on prices. The Communication states that sales information can be strategic, but in practice it is difficult to detect such cases. For example, although turnover information is related to the level of sales of a particular product and maybe strategic, the same situation may not be relevant to a wider range of products. For example, the aforementioned case against tractor manufacturers in the UK was one of the first when the European Commission banned the exchange of information with further analysis of the effects of restricting competition. Eight major tractor manufacturers in the UK exchanged three types of information through their trade associations: 1) on sales in the industry, in particular, broken down by product, time period, and territory; 2) the total sales volume and market share of each individual manufacturer, in particular, broken down by goods, terms and territories; 3 ) on sales of dealers in the distribution network of each participant with a breakdown of imports and exports in their territories (Capobianco 2004).

\section{Demand}

The exchange of individual information on the level of demand is understudied. On the one hand, aggregate information on demand (for example, in the form of market research) can contribute to the development of the enterprise. On the other hand, individualised information about demand can constrain competition depending on market characteristics. For example, in the Palaces Parisiens case, the French Competition Council fined six luxury hotels for repeatedly exchanging information on the market regarding the average price per room, revenue per room and occupancy rate (calculated by dividing the number of rooms rented by the number of rooms available for that period).

\section{Costs}

Cost information is also ambiguous, as is demand: on the one hand, if it is aggregated, it can generate efficiency through benchmarking. On the other hand, it can help allocate cartel quotas and thus facilitate coordination, as in the presence of asymmetric costs, cartel members must redistribute production in favour of the most profitable member.

\section{Research and Development (R\&D), Technology}

Exchange of R\&D information in accordance with Article 101(1) of the TFEU may substantially affect the innovative capacity of the enterprise, which constitutes one of the parameters of competition.

\section{Investment Plans}

By disclosing its investment plans, the company can thereby inform competitors of its intentions: for example, the announcement that the company plans to acquire a new facility to better serve customers in a particular industry; a press release stating that the company plans to invest in a recently acquired facility.

\section{Individual Production, Production Capacity}

The exchange of information on the volume of products produced and sold eliminates uncertainty regarding the behaviour of competitors and thus facilitates the monitoring of the market situation. As for the individual notification of the projected volume of production, then by disclosing its production plans, the 
company essentially discloses to competitors the information about its intentions. The opposite opinion is that production plans are not binding, but enterprises will adjust their output after one of their competitors announces a production cut. Even in the absence of such an announcement, information about production plans can contribute to collusion.

\section{Orders and Deliveries}

Supply information can be strategic because it gives a clear idea of the level of sales of the company. Thus, in the Steel Beams case (Federal Trade Commission... 2014; InfoCuria 1993; Case 38907 Steel Beams 2006), the European Commission authorised a weekly exchange of information on orders and deliveries by individual companies in each member state. In its assessment, the European Commission considered the fact that the European market for these products was oligopolistic and the products were homogeneous.

\section{General Information about the Business}

The consequences of information exchange in this area should be assessed on a case-by-case basis, depending on the features of the exchange and the market. Thus, in the case of colour semiconductor manufacturers, the European Commission has condemned the regular exchange of information on research and development, production, sales promotion, raw material supply, commercial management, data processing, and overall business strategy. The Commission concluded that the information exchanges violated the requirements of Article 101(1) of the TFEU, as the undertakings concerned developed an oligopoly in respect of a number of products covered by the agreements (Bovet 2011).

If one of the main criteria in evaluating information exchange agreements is to eliminate uncertainty about a competitor's behaviour, then in assessing the importance of information content the main question should be whether the analysed information can allow to predict a competitor's behaviour in trade and adapt to it, that is, to limit the independence of this enterprise in the decision-making process and to limit competition in the relevant market. Notably, the anti-competitive information exchanges are severely sanctioned within the framework of the competition legislation not only in EU member states. For example, in China and Brazil, similar illegal actions are also subject to criminal prosecution. Next, this study considers examples of significant violations of EU competition legislation, when high fines were imposed on: flat glass manufacturers; suppliers of galvanised steel tanks; modelling agencies and associations; a group of mobile companies; importers of bananas; group of tour operators; vegetable oil producers and industry association; companies that offered television services; car companies; waste management companies and associations; industry association and dairy producers; oil companies.

\section{Case against T-Mobile Netherlands BV, KPN Mobile NV, Orange Nederland NV, Vodafone Libertel NV (2009)}

The case against $T$ Mobile Netherlands BV ( $T$ Mobile), KPN Mobile NV (KPN), Orange Nederland NV (Orange) and Vodafone Libertel NV (Vodafone) is important in terms of understanding the concept of "concerted practice": establishing a causal link between agreed actions and market behaviour of enterprises, evaluation of evidence in accordance with the rules of national competition legislation, sufficiency to prove the violation of one meeting or the necessary concerted action on a regular basis over a long period. The decision of the European Court is essentially an opinion in the legal analysis of exchanges of information between competitors. Finally, the decision contains interesting but, in the opinion of European experts, controversial wording for the evaluation of information exchange.

The exchange of information between competitors has recently become one of the priorities for European competition authorities. Penalties imposed on banana importers, high-end cosmetics suppliers, school managers, hotels, and other companies have contributed to an increasingly conservative approach to the interpretation of the application of competition legislation in this area. In many cases, fines must deter companies and trade associations from benchmarking, gathering market information, publishing statistical performance, and other information that could lead to anti-competitive effects.

\section{The Case Against Oil Companies and Industry Associations (Spain)}

Spain's National Competition Committee fined 5 major oil companies totalling 32 million euros. In the summer of 2013, after many complaints and reports pointing to insufficient competition in the gasoline distribution sector in Spain and higher retail prices than in neighbouring countries, the investigative department conducted various inspections at the offices of 5 major 
oil companies and their industry association. Using the information obtained during these inspections and subsequent research, the Competition Authority prepared charges against companies for coordinating information related to prices, customers, commercial conditions, and the exchange of official commercial information in the automotive fuel market (decision of the National Competition Committee of Spain dated February 20, 2015) (Annual report on competition policy... 2015). The Spanish National Competition Committee imposed a fine of 20 million euros on REPSOL, 10 million euros on CEPSA, 1.3 million euros on DISA, 800000 euros on GALP and 300000 euros on MEROIL.

\section{FEATURES OF INFORMATION EXCHANGE AND SPECIFIC ASPECTS OF THE PROCESS DUE TO THE CIRCUMSTANCES}

The exchange of information is more likely to have a restrictive effect on competition if the undertakings involved in the exchange have sufficiently large market shares. Interpretation of a "sufficiently large" market share depends on each particular case. At present, there is no clear threshold to ensure legal certainty in this matter. Some European experts are proposing to introduce a secure area for the exchange of actually generalised information, that is, information that would not allow the recognition of an individualised level of information of the company, between competitors who "do not cover" more than $60 \%$ of the market. The comprehensive factual assessment provided for by the European Commission Regulation should only be carried out if this threshold is exceeded (European rules... 2010; Sofia Competition Forum 2011). The properties of information determine the features of information exchange; therefore, they are very similar.

\section{Frequency and Forms of Information Exchange}

The frequency of information exchange is crucial for its assessment as a form of prohibited behaviour of companies. As a rule, the more frequent the exchange of information between competitors, the more favourable are the conditions for coordinating the market behaviour of enterprises. Frequent exchange of information facilitates the coordinated market behaviour of enterprises and reduces or even eliminates their willingness to compete with each other.

\section{Public/non-Public Exchange of Information}

If the exchange of information is available on the same terms for all buyers and competitors, and not just for the companies involved in the exchange, the probability that the exchange of information will lead to collusion in the market is reduced. As already mentioned, the exchange of public information is also unlikely to be a violation of competition rules (BeharTouchais 2015; OECD 2014). In carrying out business activities, companies usually disclose and disseminate public information about their prices, characteristics, quality, use of products and services, etc. (Sofia Competition Forum 2011). This, however, is only true for actual public information. If the costs of collecting data (for example, by sampling customers) are so high as to prevent other competitors and consumers from using this data, then, as mentioned earlier, it is possible that the market transparency achieved through the exchange will benefit only some companies, which risks that this transparency will lead to anti-competitive practices.

\section{Direct and Indirect Exchange of Information}

A very important component of assessing the exchange of information between competitors is the analysis of its mechanism - whether it is carried out in direct exchange between enterprises, or indirectly within the association of enterprises or other structure that acts on their behalf or protects their economic interests. In practice, in most cases, information exchange takes place with the involvement of associations, as a result of which their activities are also subject to analysis in order to establish forms of prohibited conduct in accordance with competition legislation (New York Amends Credit... 2011).

As a general rule, the exchange of information between competitors should not be considered a breach of competition legislation if the association or other entity acting on their behalf does not function as: (1) a forum for meetings of cartel members; (2) organisation for the issuance of anti-competitive recommendations or forecasts for the market behaviour of its members; (3) a clearinghouse that reduces or eliminates the level of uncertainty about the functioning of competition in the market (Sofia Competition Forum 2011; New York Amends Credit... 2011).

\section{Unilateral and Bilateral Exchange of Information}

The exchange of information can be unilateral or bilateral, depending on whether companies provide their commercial information to competitors unilaterally, or take part in the mutual exchange of such information. A situation in which only one company 
discloses confidential commercial information to its competitors is likely to be considered a violation of competition legislation (Sofia Competition Forum 2011; Østerud and Steen 2020). In addition, as already mentioned, if the company receives strategic data from a competitor (in a meeting, by mail or in electronic form), it is considered that it has accordingly adapted its behaviour in the market. As will be indicated in the second section of the case study, this assumption can be refuted if the company provides evidence that it has clearly stated to its competitor that it does not want to receive data on its business activities (Posada and Frutos 2014).

In determining the impact of the agreement on competition, it is necessary to take into account the following factors: the real conditions of the conclusion and implementation of the agreement, especially the economic context of the behaviour of the parties to the agreement; the type of goods or services and the actual structure of the relevant market (Commission's Guidelines... 2001). Thus, the exchange of information causes two problems in terms of protecting economic competition: it can facilitate collusion and lead to restrictions.

\section{Collusion Facilitation}

It is generally accepted that three elements must be adhered to in order to ensure a merger: the ability to reach an agreement, the ability to monitor compliance with agreements, and the ability to correct deviations from the agreement.

\section{Restriction of Competition}

The exchange of information can restrict competition at two levels: competitors who are not participants in the exchange and between participants in the exchange. It is obvious that actual competitors who do not take part in the exchange will be placed at a competitive disadvantage because they do not consider the information exchanged, while potential competitors may face high barriers to market entry, regardless of whether they decided to join this exchange. If they do not join, they will not be able to compete fairly with exchange participants, who benefit from more accurate and detailed data. If they join, they will have to disclose their confidential information so that other competitors can take immediate action against them. Thus, as already mentioned, the exchange of information can have anti-competitive effects by increasing the external resilience of the cartel.
An anti-competitive restriction may arise in the same market where information is exchanged with respect to independent competitors. This may also be the case for third parties in the relevant market. For example, by exchanging information in a high-level market, vertically integrated companies may be capable of increasing the price of a key component for a downstream market in order to increase the costs of their competitors in it (Behar-Touchais 2015). There are also aspects of information exchange that to some extent, restrict competition but are specific in nature due to specific circumstances. These include:

\section{Exchange of Information in Procurement Markets}

Procurement markets are subject to legal transparency requirements to avoid abuse by the public sector. However, full transparency of the procurement process and its results can facilitate collusion. In particular, it is easier to engage in collusion in open tenders, which facilitate communication between bidders, than in closed tenders, where bidders make a "better and final" offer.

\section{Information Exchange in the Context of the Regulatory Regime - REACH}

Regulation (EC) No 1907/2006 of the European Parliament and of the Council of 18 December 2006 concerning the Registration, Evaluation, Authorisation and Restriction of Chemicals (REACH), establishing a European Chemicals Agency, imposes the obligation to share and jointly present technical data, in particular related to its inherent properties. REACH is not a noncompetitive area: the Regulation explicitly prohibits the exchange of information on market behaviour, in particular on production capacity, production or sales volumes, import volumes, or market share (Article 25 Para. 2). Although REACH only makes provision for the exchange of technical data, in some cases even such data may lead to restrictions of competition.

\section{Information Exchange in the Context of Economic Concentration}

Prior to or during discussions on joint venture opportunities, acquisitions, or mergers, the parties should exchange information, especially during the due diligence procedure, to consider whether they wish to join the proposed transaction. Therefore, the application of Article 101(1) of the TFEU should be less stringent, provided that certain precautionary measures are taken. The reasonableness of information exchange depends on several factors, such as the competitive sensitivity of the transaction (i.e., whether 
the parties are direct competitors); competitive sensitivity of the information; proximity to closing (i.e., the closer to the completion of the transaction, the more necessary the exchange of information).

\section{Information Exchange in the Context of the B2B Platform ("Business for Business")}

For several years, starting in the 2000s, the European Commission also considered the exchange of information in the context of new forms of online trade. In particular, the European Commission has carefully examined whether online trading systems can allow a participant to access confidential information about its competitors or their customers. The speed with which information spreads over the Internet and its global reach allows B2B and other online services to implement virtual meetings in which competitive information can be exchanged (Sattler 2012). B2B stores allow industrial buyers and sellers to conduct transactions online and via the Internet. On the one hand, they increase efficiency by integrating markets, reducing information retrieval costs, and improving inventory management, which ultimately leads to lower consumer prices. On the other hand, they can be an ideal place to engage in collusion by increasing transparency and facilitating the exchange of information (Rivas and Van De Walle De Ghelcke 2012).

\section{Potential Pro-Competitive Result of Information Exchange}

The existence of an anti-competitive object or the result of the exchange of information between competitors is an element of the infringement under Article 101(1) of the TFEU. But in cases where the exchange of information is not part of the cartel between enterprises, the competitive assessment should include an assessment of its potential pro- and anti-competitive results. As already mentioned, the exchange of information in certain cases can serve as a tool for maintaining a competitive market structure (Bovet 2011), in particular through investment decisions and organisational training, product positioning, consumer benefits, mitigation of the "winner's curse", market integration.

In many EU member states, competition authorities allow forms of "communication" between competitors where clear consequences of performance improvement are established. In these cases, compliance with competition laws balances the potential restrictive effects of interaction between competitors with the potential benefits to consumers. Another important requirement that an information exchange agreement must meet is the criterion of necessity: the exchange of information must be necessary to achieve efficiency. In the Communication, the European Commission clarifies that the parties will need to demonstrate that the subject matter, aggregation, limitation, confidentiality, and periodicity of the data, as well as the sampling of data for exchange, carry minimal risks and are indispensable for efficiency.

To comply with the block exemption requirements, the information exchange agreement must also satisfy two additional requirements: the "transfer" of efficiency gains to consumers and the impossibility of eliminating competition in respect of a significant part of the goods concerned (Paragraphs 103-104 of the Communication). "Transfer to consumers" should be such as to override restrictive effects on competition caused by information exchange, for example, when the market power of the parties to the information exchange agreements is low, it is more probable that the efficiency gains will affect consumers so much that they outweigh restrictive effects on competition, and vice versa - the higher the bargaining power, the less likely consumers are to benefit (Villani 2016; Wait 2011).

Responsibility for anti-competitive exchange of information between competitors. If the assessment of the above conditions of exemption indicates that the exchange of specific information between competitors is not allowed, it will be considered a violation of Article 101 of the TFEU and/or the relevant article of the national competition law (for example, as a violation of Article 6 of the Law of Ukraine "On protection of economic competition"). Enterprises and associations of enterprises involved in the exchange of information are liable for violations. In these cases, the competition authority must impose sanctions on enterprises or associations of enterprises in accordance with the Law "On protection of economic competition" in the amount not exceeding $10 \%$ of the total revenue of the business entity from sales for the previous financial year (Ukraine has a similar liability for anti-competitive concerted actions) (Rivas and Van De Walle De Ghelcke 2012).

\section{CONCLUSIONS}

An analysis of European practice has concluded that anti-competitive information exchanges are most probable in markets that are transparent, highly 
concentrated (especially oligopolistic), simple and stable, where new players rarely appear, including through significant entry barriers to such markets. Enterprises involved in the exchange of information, in most cases, are homogeneous in terms of their value, product range, market share. Markets with such characteristics create favourable conditions for enterprises to conclude tacit agreements, successfully monitor their implementation and apply sanctions for evasion of agreements. Under such conditions, the result of the development of competitive relations proceeding from the information exchange depends both on the initial characteristics of the market where the exchange takes place, and on possible changes in these characteristics that may arise as a result of the exchange of information. Therefore, it is necessary to analyse not only the initial characteristics of the market in which the exchange of information takes place but also the forecast of the market situation without such an exchange.

The need for regulation such as the Guidelines is justified not only by the possibility of substantial anticompetitive effects (especially if the exchanges took place within the existence/maintenance of the cartel) but also by the importance of market information availability and the positive effects of information exchanges. Although this document should not duplicate the provisions of the Law of Ukraine "On protection of economic competition" but will be of a recommendatory nature - legal principles are established to ensure certainty in cases of information exchanges between competitors, as well as to encourage voluntary compliance with fair market rules. This is important to protect the legal position of the competition authority during the consideration of relevant cases in the courts. Therefore, the adoption of the Guidelines (recommendation clarifications) in Ukraine is necessary for all target groups: the Antimonopoly Committee of Ukraine, companies, associations, and chambers of commerce, legal scientists (lawyers, judges), society in general. Given Ukraine's aspirations for European integration, it is important to consider the approaches adopted in the European Union to address these issues during the development of such a document.

Taking into account the experience of European countries and analysing the relevant documents, the following structure of Recommendation clarifications for application by the bodies of the Antimonopoly Committee of Ukraine is proposed: 1) general part (purpose and scope); 2) analysis of characteristics related to the circumstances and mechanisms of information exchange, as well as analysis of the parameters of the exchanged information; 3) recommendations on the admissibility of information exchanges with an emphasis on cases where there may be risks of distortion and restriction of competition.

\section{REFERENCES}

Annual report on competition policy developments in Spain. 2015 (https://one.oecd.org/document/DAF/COMP/AR(2016)21/en/ pdf).

Bakalinska, Olga V., Oleksandr V. Bezyh, Oleksandra V. Kologoida, Iryna V. Lukach, Nino B. Patsuria, and Valentyn S. Scherbyna. 2017. Competition Law of Ukraine. Kyiv: Lira.

Behar-Touchais, Martine. 2015. "Exchange of information: The court of justice of the European Union confirms that strategic information exchange is a restriction of competition by object (dole food, dole fresh fruit Europe)". Concurrences 2: 3-10.

Bovet, Christian. 2011. Information exchange among undertakings in EU competition law. Genève: MBL Thesis.

Boychuk, Natalia. 2017. "Ukrainian retail: moderately public and slightly transparent”. All Retail Magazine 6: 26-27.

Capobianco, Antonio. 2004. "Information exchange under EC competition law". Common Market Law Review 41(5): 12471276.

Case 38907 Steel Beams. 2006. Antitrust/Cartel Cases. (http://ec.europa.eu/competition/elojade/isef/case details.cfm ?proc_code=1_38907.c).

Case C-8/08 T-Mobile Netherlands BV and Others v Raad van bestuur van de Nederlandse Mededingingsautoriteit. 2009. (https://eur-lex.europa.eu/legalcontent/EN/ALL/?uri=ecli:ECLI:EU:C:2009:343).

Comisión Federal de Competencia Económica. 2015. Federal Economic Competition Law. (https://www.cofece.mx/wpcontent/uploads/2018/03/Federal_Economic_Competition_La w.pdf).

Commission Decision, UK Agricultural Tractor Exchange, OJ L 68/19. 1992. (http://eur-lex.europa.eu/legal-content/EN/TXT/ ?uri=CELEX\%3A31992D0157)

Commission's Guidelines on the applicability of Article 81 to horizontal co-operation agreements. 2001. Official Journal of the European Union, 44. (https://eur-lex.europa.eu/legalcontent/EN/TXT/?uri=CELEX\%3A32001Y0106\%2801\%29).

Communication from the Commission - Guidelines on the applicability of Article 101 of the Treaty on the Functioning of the European Union to horizontal co-operation agreements. 2011. Official Journal of the European Union, 54. (https://eurlex.europa.eu/legal-content/EN/ALL/?uri=CELEX\% 3A52011XC0114\%2804\%29).

Consolidated version of the treaty on the functioning of the European Union (Treaty on the Functioning of the European Union). 2012. Official Journal of the European Union 55. (https://eurlex.europa.eu/LexUriServ/LexUriServ.do?uri=CELEX:12012E /TXT:en:PDF).

European Commission. 1978. Seventh Report on competition policy. Brussels: ECSC. (https://ec.europa.eu/competition/ publications/annual_report/ar_1977_en.pdf).

European rules for information exchange between competitors. 2010. (http://www.eubelius.com/en/spotlight/european-rulesinformation-exchange-between-competitors).

Federal Trade Commission and the U.S. Department of Justice. Antitrust Guidelines for Collaborations Among Competitors. 2000. (https://www.ftc.gov/sites/default/files/documents/ public_events/joint-venture-hearings-antitrust-guidelinescollaboration-among-competitors/ftcdojguidelines-2.pdf). 
Federal Trade Commission. FTC, DOJ. Issue antitrust policy statement on sharing cyber security information. 2014. (https://www.ftc.gov/news-events/press-releases/2014/04/ftcdoj-issue-antitrust-policy-statement-sharing-cybersecurity).

Government of Canada. 2009. Competitor Collaboration Guidelines. (http://www.competitionbureau.gc.ca/eic/site/cbbc.nsf/eng/03177.html\#ccg-3.8).

Horizontal Information Exchanges. 2012. (http://www.eucomplaw. com/article-101/horizontal-information-exchange/)

InfoCuria. 1993. Cases C-89/85, C-104/85, C-114/85, C-116/85, C$117 / 85$ and C-125/85, ECR I-1307. Ahlström Osakeyhtiöand Others v. Commission. (http://curia.europa.eu/juris/liste.jsf? num $=C-89 / 85 \&$ language $=$ en).

Information cartels: a guide for undertakings. 2016. (http://www.lexology.com/library/detail.aspx?g=00f77801518c-4484-9c95-e966c9ae7219).

Information Exchanges Between Competitors under Competition Law. 2010. Organisation for Economic Co-operation and Development. (http://www.oecd.org/competition/cartels/ 48379006.pdf)

Lourenço, Nuno Calaim. 2017. "Information exchanges between competitors from a competition law perspective - the problem of premature exchanges of sensitive information in the context of merger control". EU Law Journal 4(1): 78-101. https://doi.org/10.21814/unio.4.1.8

McDavid, Janet, and Gianni De Stefano. 2016. Global laws inconsistent when competitors talk among themselves. (http://ehoganlovells.com/rv/ff00268fcc5c5e4b51ab87292d41 96b5994c31ae).

New York Amends Credit for Reinsurance Regulation, Relaxing Unauthorized Reinsurer Collateral Requirements. 2011. (https://www.lexology.com/library/detail.aspx?g= 271430a46314-46a2-af4c-3fdcabc1ee78).

Notice concerning agreements, decisions and concerted practices in the field of co-operation between enterprises. 1968. (https://eur-lex.europa.eu/legal-content/HU/TXT/?uri= CELEX:31968Y0729(01)).

OECD. OECD reviews of competition legislation and policy: Ukraine 2016. 2016. (https://www.oecd.org/daf/competition/Ukraine\% 20Highlights\%20UKR.pdf).

OECD. Strategic Orientations of the Secretary-General. Meeting of the OECD Council at Ministerial Level. 2014. Retrieved November 11, 2020 (https://www.oecd.org/mcm/MCM-2014Strategic-Orientations-SG.pdf).
Østerud, Eirik, and Frode Steen. 2020. "Norwegian cartels: Law, policy, registration and practice under the price and competition act between 1954 and 1993". Oslo Law Review 7(2): 84-104.

https://doi.org/10.18261/ISSN.2387-3299-2020-02-02

Papp, Florian Wagner. 2013. "Information exchange agreements". Pp. 130-173 in Handbook on European Competition Law: Substantive Aspects. Cheltenham: Edward Elgar Publishing.

Posada, Pedro, and Sergio Frutos. 2014. Competition Policy Applied to Information Exchanges between Competitors in the EU: Proceedings of the Spanish Competition Authority in a Recent Case. Madrid: NERA Economic consulting.

Rivas, José, and Geoffroy Van De Walle De Ghelcke. 2012. Concerted practices and exchange of information: An overview of EU and national case law. (http://awa2013.concurrences.com/business-articlesawards/article/concerted-practices-and-ex0change).

Sattler, Mario. 2012. Opening governmental traffic management infrastructure for the mutual benefits of authorities and logistics-river information services in Europe. In 19th Intelligent Transport Systems World Congress, ITS 2012. Vienna: AustriaTech.

Skliar, Sergey V. 2014. Application of competition law. Practice of Ukraine, EU, Russia and USA. Kyiv: Justinian.

Sloan, Peter. 2014. "The reasonable information security program". Richmond Journal of Law and Technology 21(1): Article No. 3.

Sofia Competition Forum. 2011. Guidelines on information exchange between competitors. (https://unctad.org/system/files/nonofficial-document/ccpb_SCF_InfoSharing_en.pdf).

Švirinas, Daivis. 2012. "The assessment of information exchange agreements between competitors from the perspective of competition law of the EU and of the Republic of Lithuania". Jurisprudence 19: 87-119.

Verkhovna Rada of Ukraine. 2001. Law of Ukraine "On protection of economic competition". Information of the Verkhovna Rada of Ukraine 12: 64-120.

Villani, Luca. 2016. The E-turas case: when concerted practices meet technology. (http://rivista.eurojus.it/the-e-turas-casewhen-concerted-practices-meet-technology/).

Wait, Amanda L. 2011. Competitor Information Exchanges: Practical Considerations from FTC Consent Decrees. (https://www.huntonak.com/images/content/3/6/v2/3664/Com petitor_Information_Exchanges.pdf).

\section{DOI: https://doi.org/10.6000/1929-4409.2021.10.53}

(C) 2021 Bakalinska et al.; Licensee Lifescience Global.

This is an open access article licensed under the terms of the Creative Commons Attribution Non-Commercial License (http://creativecommons.org/licenses/by-nc/3.0/) which permits unrestricted, non-commercial use, distribution and reproduction in any medium, provided the work is properly cited. 